\title{
Optical Imaging of Breast Cancer Using Hemodynamic Changes Induced by Valsalva Maneuver
}

\author{
Optische Brustbildgebung: Valsalva-Manöver zur Induzierung von \\ hämodynamischen Veränderungen
}

Authors

Affiliations
N. F. Schreiter ${ }^{1}$, N. Volkwein ${ }^{1}$, P. Schneider ${ }^{1}$, M. H. Maurer ${ }^{1}$, S. Piper ${ }^{2}$, C. Schmitz ${ }^{2}$, A. Poellinger ${ }^{1}$

Department of Radiology, Charité, Berlin

Berlin Neurolmaging Center (BNIC), Neurology, Charité, Berlin
Key words

- breast

- optical imaging

- hemodynamic changes

eingereicht 11.7.2012

akzeptiert 19.11.2012

Bibliography

Dol http://dx.doi.org/

10.1055/s-0032-1330446

Published online: 14.3.2013

Fortschr Röntgenstr 2012; 184 :

358-366 @ Georg Thieme

Verlag KG Stuttgart · New York . ISSN 1438-9029

\section{Correspondence}

\section{Dr. Nils F. Schreiter}

Klinik für Strahlenheilkunde, Charité

Campus Virchow-Klinikum

Augustenburger Platz 1

13353 Berlin

Germany

nils.schreiter@charite.de

Tel.: ++ 49/30/450657299

Fax: ++ 49/40/519914

\section{Zusammenfassung}

$\nabla$

Ziel: Zu überprüfen, inwieweit die optische Mammografie eine durch ein Valsalva-Manöver induzierte Veränderung der Hämodynamik zur Läsionsdetektion und Charakterisierung nutzen kann.

Material und Methoden: 30 Patientinnen unterzogen sich vor Brustbiopsie einer optischen Untersuchung mit Valsalva-Manöver am Tomografen DYNOT 232. Die Konzentrationsänderungen von Oxyhämoglobin und Deoxyhämoglobin wurden dreidimensional zeitaufgelöst rekonstruiert. Die Parameter "full width at half maximum“ (FWHM), „time to ten“ (TTT) und „peak amplitude“ (PA) aus den zeitaufgelösten Kurvenverläufen wurden farblich kodiert grafisch dargestellt. Die errechneten Bilder wurden von 2 erfahrenen Auswertern getrennt bezüglich Detektionsrate, Grad der Sichtbarkeit und dem Auftreten von Zusatzläsionen evaluiert und eine ROC-Analyse durchgeführt.

Ergebnisse: 10 Patientinnen waren aufgrund von Artefakten oder nicht regelrechten Valsava-Manövern nicht auswertbar. Die ROC-Analyse zeigte AUC-Werte $(0,393-0,779)$ die sich nicht von der Zufallswahrscheinlichkeit unterschieden. Die höchsten AUC-Werte ergab das FWHM-Model (AUC: 0,779, Detektions- [60-70\%] und Zusatzläsionsraten [55-70\%]). Das PA-Modell zeigte zwar die höchsten Detektions- (70-90\%) aber auch die höchsten Zusatzläsionsraten (80-90\%). Die Konkordanzraten beider Auswerter bei malignen Läsionen waren zufriedenstellend $(0,524-1,0)$.

Schlussfolgerung: Die Artefaktanfälligkeit und die zahlreichen falsch positiven Zusatzläsionen lassen in unserer Studie die optische Beurteilung der Hämodynamik mittels Valsalva-Manöver als nicht vielversprechend erscheinen.

\section{Abstract \\ $\nabla$}

Purpose: To investigate whether changes in hemodynamics induced by Valsalva maneuver can be exploited for detecting and characterizing breast lesions by optical mammography.

Materials and Methods: 30 women underwent optical imaging of the breast using a DYNOT 232 system and performing Valsalva maneuvers prior to biopsy. Changes in light absorption due to changes in oxyhemoglobin and deoxyhemoglobin concentrations were recorded volumetrically and in a time-resolved manner. The parameters full width at half maximum (FWHM), time to ten (TTT), and peak amplitude (PA) of the reconstructed concentration time curves yielded color-coded maps of the breast which were separately evaluated by two experienced readers for detection rate, degree of visibility, and detection of additional lesions. ROC analysis was performed with the evaluation results.

Results: 10 patients were excluded from analysis due to artifacts or inadequately performed Valsalva maneuver. The resulting 20 patients showed a clear increase in oxygenated and deoxygenated hemoglobin concentration after the onset of the Valsalva maneuver. ROC analysis yielded AUC values $(0.393-0.779)$ that did not differ from random probabilities. The highest AUC values were obtained for FWHM (AUC: 0.779, detection rates [60-70\%], identification of additional lesions [55-70\%]). PA analysis had the highest detection rate $(70-90 \%)$ but also the highest identification of false-positive additional lesions ( $80-90 \%$ ). The concordance rates of the two readers for malignant lesions were satisfactory $(0.524-1.0)$.

Conclusion: Our study revealed susceptibility to artifacts and a large number of false-positive additional lesions, suggesting that the evaluation of hemodynamic changes after Valsalva maneuver by optical imaging is not a promising method. 


\section{Introduction}

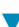

In Western societies breast cancer is the most common malignancy in females [1].

The size of the primary tumor closely correlates with the presence of metastatic disease, and the prognosis of women with breast cancer is better the earlier the cancer is detected [2-5]. An imaging test for breast cancer should therefore detect lesions early, when they are still small. Moreover, the method should have sufficient specificity to reduce the need for additional diagnostic tests. All currently available imaging modalities have limitations, fueling the search for alternative techniques.

Optical near-infrared (NIR) imaging of the breast is one of several diagnostic approaches that have been pursued to improve the diagnosis of breast cancer [6 - 14]. While established techniques for breast imaging, including mammography, ultrasound and magnetic resonance imaging (MRI), mainly rely on the assessment of morphology, optical imaging also provides physiologic information, including information at the cellular and molecular level $[15,16]$. The hemoglobin concentration, oxygen saturation, and water and collagen content of the breast can be evaluated using optical imaging. Optical imaging therefore has the potential to become a valuable alternative or adjunct to established breast imaging modalities $[17,18]$.

Optical methods were first used to visualize breast cancer in the $1920 \mathrm{~s}$, but these attempts ultimately failed. The method was abandoned until the advent of diffuse optical imaging (DOI), which rekindled interest in optical imaging, giving rise to promising developments in recent years. Optical imaging can be performed employing endogenous contrast or exogenous contrast such as indocyanine green (ICG). DOI without the use of exogenous dyes most commonly measures contrasts resulting from differences in oxyhemoglobin and deoxyhemoglobin concentrations. These two redox forms of hemoglobin are the strong absorbers of NIR light in biological tissues, and this fact can be used to identify tissues with increased hemoglobin concentrations, such as tissues with malignant angiogenesis [19].

Initial work on DOI aimed at improving the spatial resolution of static tissue contrasts, while recently there has been an increasing interest in functional imaging. The NIRx system we use at our department additionally allows highly time-resolved acquisition and allows for rapid measurement of hemodynamic changes over time. A possible approach for improving breast cancer detection by DOI uses differences in the hemodynamic response to changes in intrathoracic pressure between malignant and normal breast tissue. The feasibility of this concept has been shown in studies of a few patients [20,21].

The aim of our study was to verify these initial observations in a prospective patient population and to test whether DOI using Valsalva maneuver can help in detecting breast cancer and differentiating between malignant and benign breast lesions.

\section{Materials and Method}

\section{$\nabla$}

The prospective study was approved by the ethics committee of our institution. Women with a suspicious finding at breast imaging that was confirmed by subsequent biopsy were included after giving written informed consent. Breast ultrasound was performed in all patients, mammography in 29 cases, and magnetic resonance imaging (MRI) of the breast in 25 women. Histological workup was performed after imaging. The exclusion crite- ria were breast biopsy within six week before optical imaging was scheduled, focal lesion near the chest wall, and history of breast cancer with suspected ipsilateral recurrence.

Between November 2008 and December 2009, a total of 30 women underwent optical imaging. They had a mean age of 53 years (range, 28 - 78 years). Histopathology of biopsy specimens demonstrated a malignant breast lesion in 19 cases and a benign lesion in 11 cases.

Diffuse optical imaging was performed using a DYNOT 232 tomographic system from NIRx Medizintechnik GmbH (Berlin, Germany). The system has been described in detail elsewhere [6]. Briefly, the DYNOT 232 is a continuous-wave system that uses near infrared light at two wavelengths, 760 and $830 \mathrm{~nm}$. The frequency-modulated light is emitted into the breast tissue by means of 31 optodes, which can both emit and detect light. This results in a total of 961 source-detector combinations - so-called optical channels - each of which is read out once approx. every $500 \mathrm{~ms}$. Using the DYNOT system, the entire breast volume is thus sampled at a rate of about $2 \mathrm{~Hz}$. The optodes are mounted on a rigid, breast-shaped plastic cup arranged in four concentric rings, and protrusion of the fibers allows adjustment to individual breast size. The breast cup is integrated into an aperture of the patient table and can be horizontally and vertically adjusted. For optical imaging, the patient is positioned prone with the breast to be imaged hanging into the optode holder through the table aperture. After attachment of the light-guiding fibers and a short automatic calibration step, the breast is scanned at rest (baseline). This step takes approx. $5 \mathrm{~min}$, during which the patient is requested to lie still. The baseline scan is followed by imaging during increased intrathoracic pressure induced by three Valsalva breathing maneuvers. The commands for the Valsalva maneuvers are given at intervals of $2 \mathrm{~min}$. The Valsalva maneuver involves forced expiration against a closed mouth and nose for $15 \mathrm{sec}$. Before the examination, the maneuver was explained in detail and practiced with the patient. Optical measurement was performed continuously for a total period of approx. $15 \mathrm{~min}$.

The acquired raw data sets were preprocessed using the NAVI software package (NIRx Medical Technologies, LLC. (NY, USA)). First, the data were smoothed with a low-pass filter of $0.15 \mathrm{~Hz}$ to minimize motion artifacts and high-frequency noise. Optical channels with a variation coefficient of more than $25 \%$ in the baseline examination were excluded from the reconstruction process. The data were then automatically reconstructed by the NAVI software as temporally resolved three-dimensional volumes of changes in the concentrations of oxygenated and deoxygenated hemoglobin relative to baseline concentrations. In this process, the breast volume is represented by a finite-element grid with 2243 nodes, which is the same for all patients and which was then interpolated to 14,000 isometric volume cubes (voxels) for display and data export. For further evaluation, the extracted time course of relative hemoglobin changes in each voxel of the breast volume during the second Valsalva maneuver was analyzed using customized Matlab scripts (The Mathworks, Inc., Natick, USA). The time courses were additionally filtered with a $0.07 \mathrm{~Hz}$ low-pass Butterworth filter and normalized to the maximum of the mean time course of each patient to account for inter-subject variability in overall signal intensity. A signal-tonoise ratio (SNR) was calculated for every voxel as the quotient of the signal intensity at the maximum of the mean time course and the standard deviation over the baseline period. Voxels with $\mathrm{SNR}<1$ were excluded from further analysis and mapping. Regions of interest (ROIs) were manually selected in the approxi- 


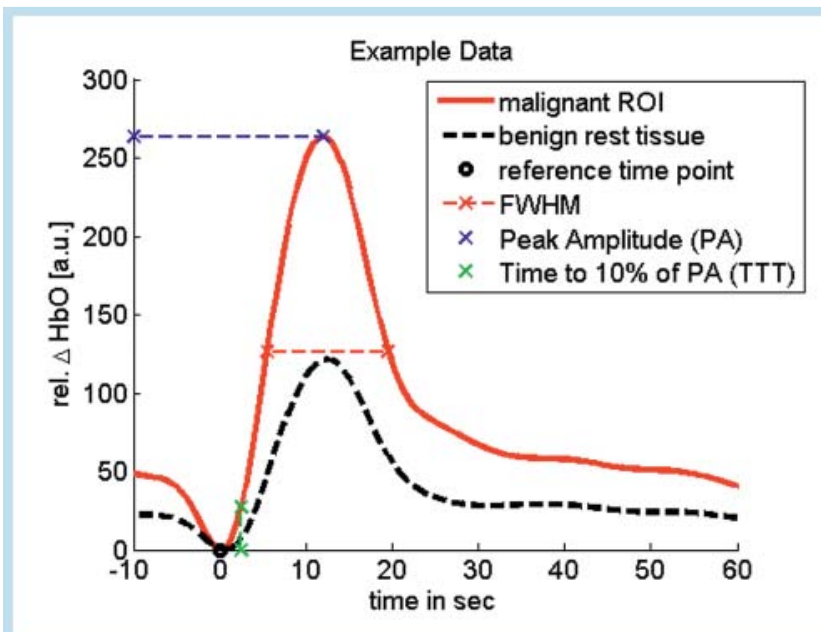

Fig. 1 Visualization of an exemplary calculation of the three different parameters full width at half maximum (FWHM), time to ten (TTT), and peak amplitude (PA).

Abb. 1 Modell einer exemplarischen Berechnung der 3 verschiedenen Parameter Full Width at Half Maximum (FWHM), Time to Ten (TTT) und Peak Amplitude (PA) mated location of the lesion corresponding to palpation and MRI or mammography. The parameters determined from each time course included full width at half maximum (FWHM), peak amplitude (PA), and time to ten (TTT), \& Fig. 1. To overcome intersubject variability in overall blood flow, the reference time point $\mathrm{t}=0$ was set to the zero of the linear regression of the increasing slope of the mean time course of each breast. The PA was measured from the minimum (base point) of the increasing slope. For display, the mean time courses in the ROI and the residual benign tissue were vertically aligned at the base point $(\bullet$ Fig. $1-4)$. Each of the three calculated parameters was color-coded and displayed in two planes of the breast (craniocaudal and mediolateral-oblique planes, similar to mammograms) ( $\bullet$ Fig. $5-7$ ).

These parametric maps were evaluated separately and in a blinded fashion by a radiologist and a nuclear medicine specialist, both with breast imaging experience. The results were documented using a standardized evaluation form. The readers had the following options: predefined lesion present (yes/no) for assessment of sensitivity; additional lesions present (yes/no) for assessment of specificity; and visibility score of predefined lesion (not visible; visible but poorer color contrast compared with other lesions; visible color contrast comparable to that of other lesions; visible).

Statistical analysis was performed using PASW (IBM, USA) including an ROC analysis and a concordance analysis using Cohen's kappa.

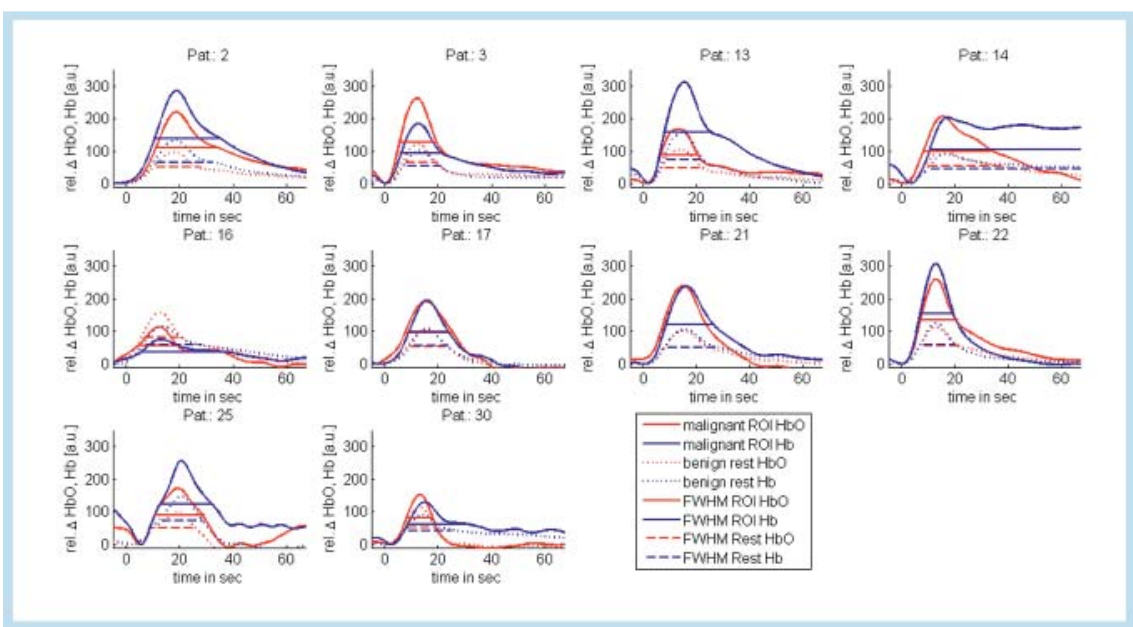

Fig. 2 Individual time curves for patients with a malignant breast lesion $(n=10)$ : Mean time curve over the malignant lesion (ROI, solid lines) and benign surrounding breast parenchyma (dashed lines) for oxygenated (red) and deoxygenated (blue) hemoglobin, respectively.

Abb.2 Individuelle Zeitkurven für Patienten mit malignen Brustläsionen ( $n=10)$ :Gemittelte Zeitkurve über die maligne Läsioen (ROI, durchgezogene Linien) und benignes Umgebungsgewebe (gestrichelte Linien) für oxygeniertes (rot) und desoxygeniertes (blau) Hämoglobin.
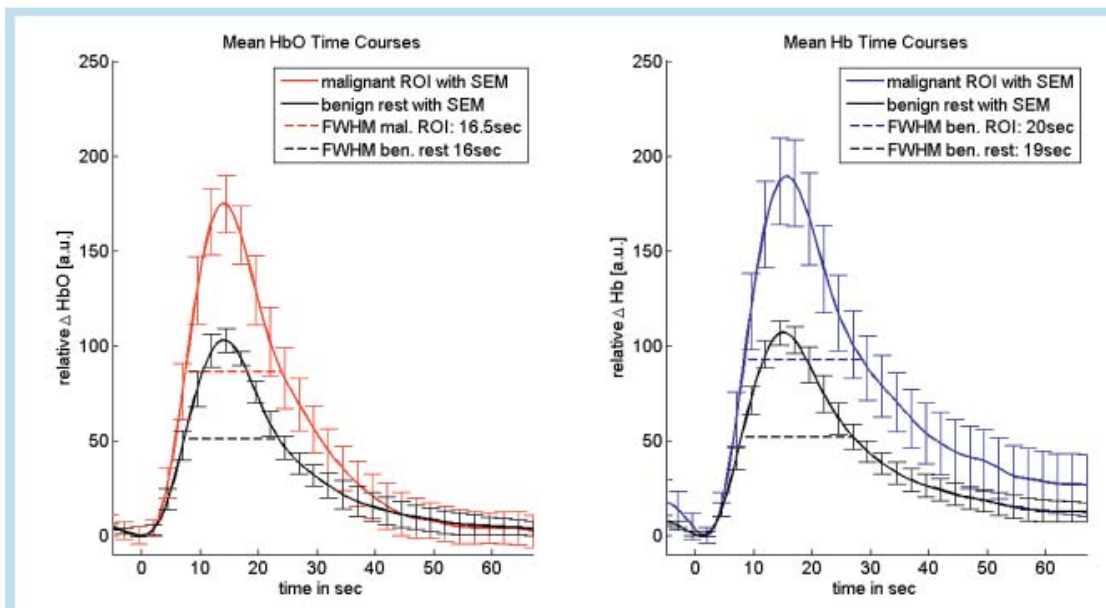

Fig. 3 Mean time curves with standard error of mean of 10 malignant lesions and surrounding benign breast parenchyma (black) for oxygenated (left, red) and deoxygenated (right, blue) hemoglobin, respectively. FWHM values are depicted with dashed lines.

Abb.3 Gemittelte Zeitkurven mit mittlerer Standardabweichung von 10 malignen Läsionen und benignem Umgebungsgewebe (schwarz) für oxygeniertes (links, rot) und desoxygeniertes (rechts, blau) Hämoglobin. FWHM-Werte sind durch gestrichelte Linien gekennzeichnet. 


\section{Results}

The raw optical imaging data of 10 of the 30 patients examined showed severe artifacts (motion artifacts due to interruption of skin-fiber coupling) or inadequate Valsalva maneuver. As a result, only twenty patients were included in the analysis, ten with benign breast lesions (six fibroadenomas [24 mm, 10-52 mm]; three fibrocystic changes; one pseudoangiomatous stromal hyperplasia, [44 mm]) and ten patients with malignant lesions (six invasive ductal carcinomas [ $24 \mathrm{~mm}, 8-40 \mathrm{~mm}$ ]; one ductal carcinoma in situ [80 mm]; two metaplastic carcinomas [19 mm, $37 \mathrm{~mm}$ ]; one T-cell lymphoma [35 mm]).

In the patients included in the analysis, an adequately performed Valsalva maneuver resulted in a marked increase in light absorption in all cases ( $\mathbf{F i g . 2}-\mathbf{4}$ ). This corresponded to a marked increase in reconstructed relative concentrations of oxygenated and deoxygenated hemoglobin in breast tissue compared to baseline concentrations.

\begin{tabular}{|c|c|c|c|c|}
\hline parameter & form of hemoglobin & reader & $\begin{array}{l}\text { detection of malignant } \\
\text { lesions }(n=10)\end{array}$ & concordance \\
\hline \multirow[t]{4}{*}{ TTT } & \multirow[t]{2}{*}{ oxyhemoglobin } & 1 & $60 \%$ & \multirow[t]{2}{*}{0.800} \\
\hline & & 2 & $50 \%$ & \\
\hline & \multirow[t]{2}{*}{ deoxyhemoglobin } & 1 & $60 \%$ & \multirow[t]{2}{*}{0.583} \\
\hline & & 2 & $60 \%$ & \\
\hline \multirow[t]{4}{*}{ FWHM } & \multirow[t]{2}{*}{ oxyhemoglobin } & 1 & $70 \%$ & \multirow[t]{2}{*}{1.000} \\
\hline & & 2 & $70 \%$ & \\
\hline & \multirow[t]{2}{*}{ deoxyhemoglobin } & 1 & $70 \%$ & \multirow[t]{2}{*}{0.524} \\
\hline & & 2 & $60 \%$ & \\
\hline \multirow[t]{4}{*}{ PA } & \multirow[t]{2}{*}{ oxyhemoglobin } & 1 & $90 \%$ & \multirow[t]{2}{*}{0.615} \\
\hline & & 2 & $80 \%$ & \\
\hline & \multirow[t]{2}{*}{ deoxyhemoglobin } & 1 & $80 \%$ & \multirow[t]{2}{*}{0.737} \\
\hline & & 2 & $70 \%$ & \\
\hline
\end{tabular}

Table 1 Detection rate of predefined malignant lesions $(n=10)$.

Tab. 1 Detektionsraten prädefinierter maligner Läsionen $(n=10)$

Table 2 Predefined benign breast lesions classified as false positive $(n=7)$ and additional false-positive lesions.

Tab. 2 Prädefinierte benigne Läsionen, die als falsch positiv klassifiziert wurden ( $n=7)$, und falsch positive Zusatzläsionen.

\begin{tabular}{|c|c|c|c|c|c|c|}
\hline parameter & form of hemoglobin & reader & $\begin{array}{l}\text { detection of benign } \\
\text { lesions }(n=7)\end{array}$ & concordance & $\begin{array}{l}\text { additional lesions in } \\
\text { all patients }(n=20)\end{array}$ & concordance \\
\hline \multirow[t]{4}{*}{ TTT } & \multirow[t]{2}{*}{ oxyhemoglobin } & 1 & $57.1 \%$ & \multirow[t]{2}{*}{0.696} & $65 \%$ & \multirow[t]{2}{*}{0.560} \\
\hline & & 2 & $71.4 \%$ & & $65 \%$ & \\
\hline & \multirow[t]{2}{*}{ deoxyhemoglobin } & 1 & $14.3 \%$ & \multirow[t]{2}{*}{0.364} & $60 \%$ & \multirow[t]{2}{*}{0.681} \\
\hline & & 2 & $42.9 \%$ & & $65 \%$ & \\
\hline \multirow[t]{4}{*}{ FWHM } & \multirow[t]{2}{*}{ oxyhemoglobin } & 1 & $14.3 \%$ & \multirow[t]{2}{*}{1.000} & $65 \%$ & \multirow[t]{2}{*}{0.681} \\
\hline & & 2 & $14.3 \%$ & & $60 \%$ & \\
\hline & \multirow[t]{2}{*}{ deoxyhemoglobin } & 1 & $57.1 \%$ & \multirow[t]{2}{*}{0.364} & $70 \%$ & \multirow[t]{2}{*}{0.479} \\
\hline & & 2 & $85.7 \%$ & & $55 \%$ & \\
\hline \multirow[t]{4}{*}{ PA } & \multirow[t]{2}{*}{ oxyhemoglobin } & 1 & $71.4 \%$ & \multirow[t]{2}{*}{0.588} & $80 \%$ & \multirow[t]{2}{*}{0.615} \\
\hline & & 2 & $85.7 \%$ & & $90 \%$ & \\
\hline & \multirow[t]{2}{*}{ deoxyhemoglobin } & 1 & $100 \%$ & $\mathrm{n} / \mathrm{a}$ & $85 \%$ & \multirow[t]{2}{*}{1.000} \\
\hline & & 2 & $85.7 \%$ & $\mathrm{n} / \mathrm{a}$ & $85 \%$ & \\
\hline
\end{tabular}
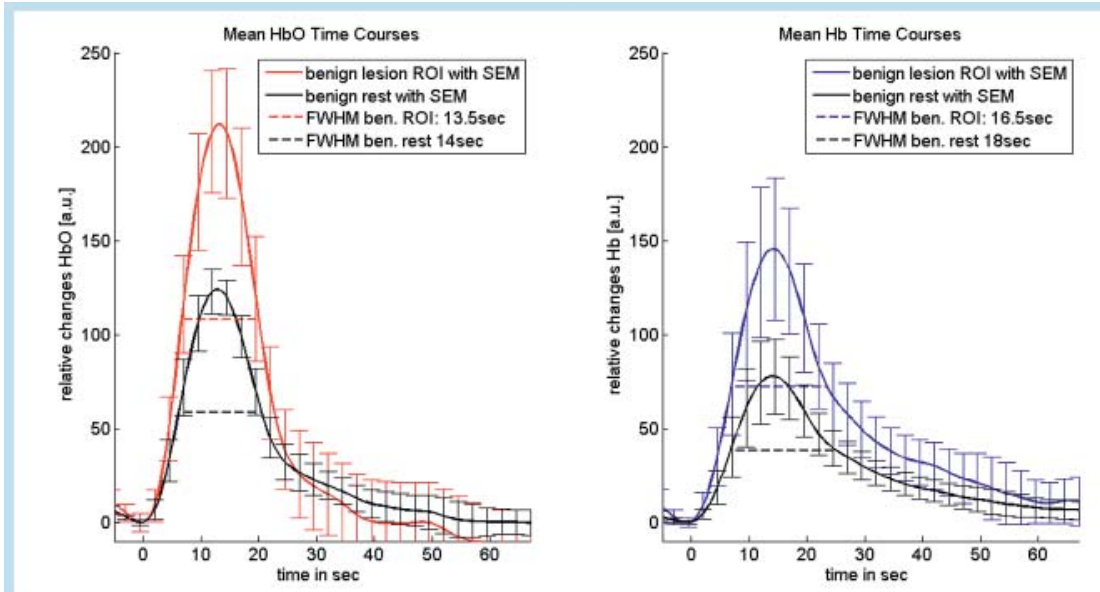

Fig. 4 Mean time curves with standard error of mean of benign lesions and surrounding benign breast parenchyma (black) for oxygenated (left, red) and deoxygenated (right, blue) hemoglobin, respectively. FWHM values are depicted with dashed lines.

Abb. 4 Gemittelte Zeitkurven mit mittlerer Standardabweichung von benignen Läsionen und benignem Umgebungsgewebe (schwarz) für oxygeniertes (links, rot) und desoxygeniertes (rechts, blau) Hämoglobin. FWHM-Werte sind durch gestrichelte Linien gekennzeichnet. 


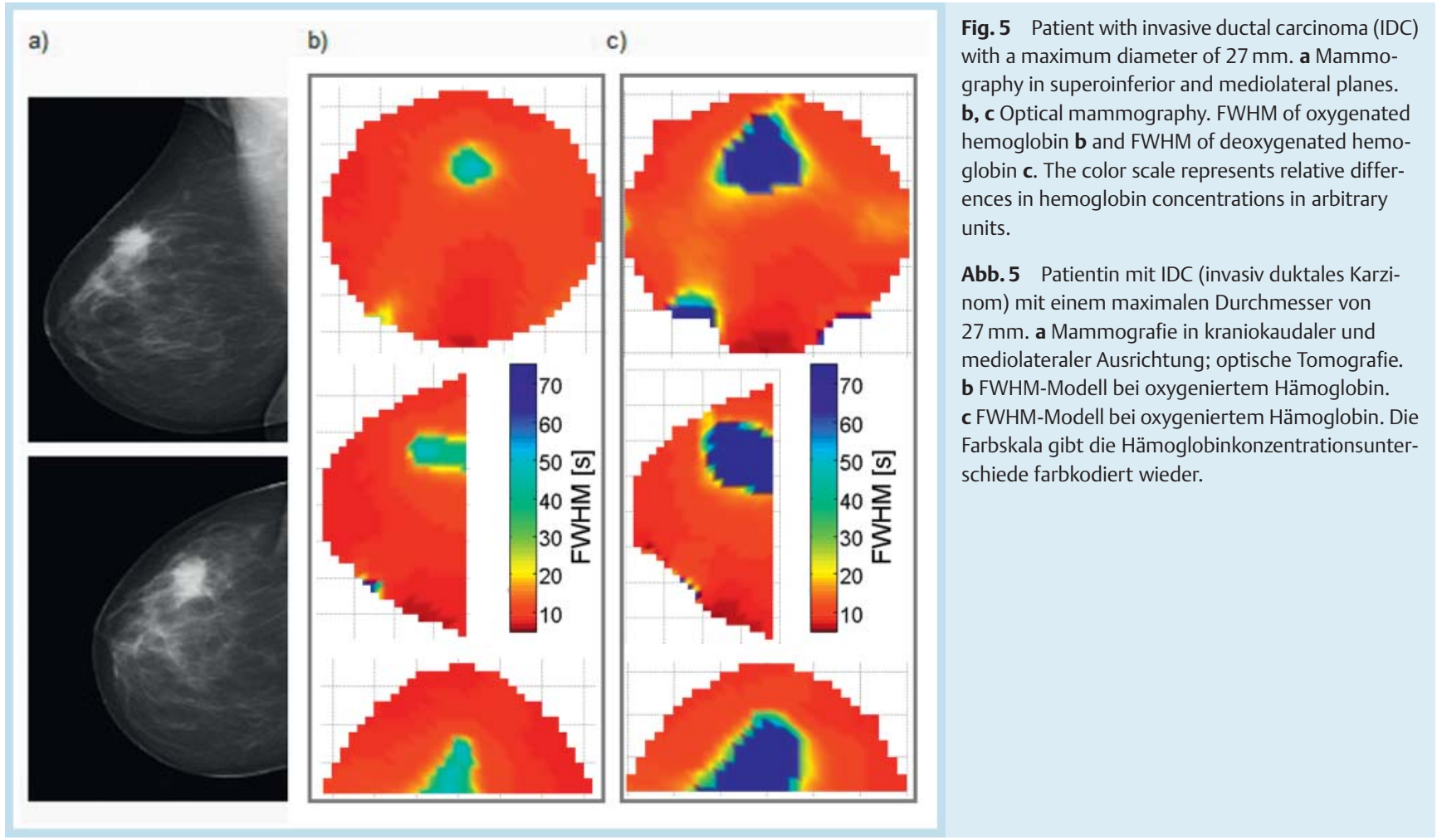

a)
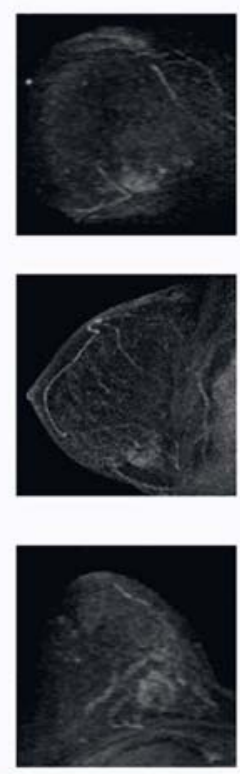

b)
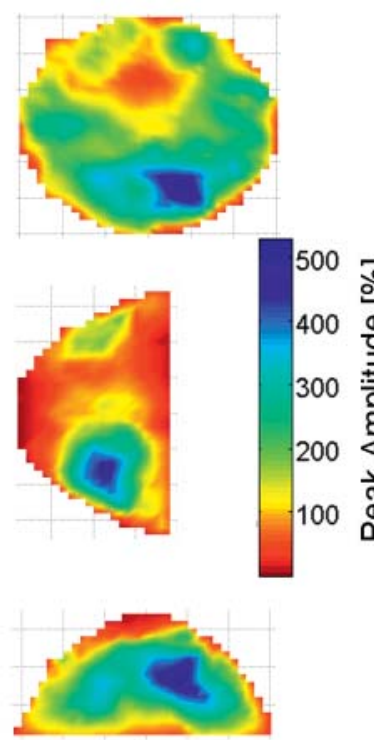

a)
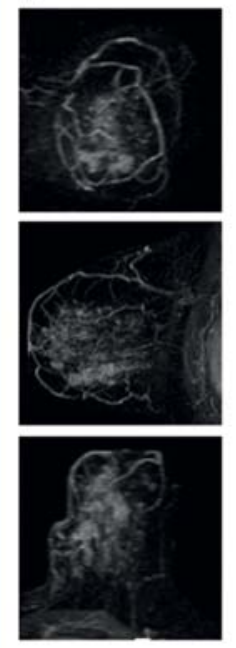

Fig. 7 Patient with DCIS of the left breast (maximal diameter: $80 \mathrm{~mm}$ ). a Imponing as hypervasculated lesion in the MRI; $\mathbf{b}$ corresponding focal region in the TTT analysis where $10 \%$ of the maximum amplitude are reached sooner.

Abb. 7 Patientin mit DCIS der linken Brust (maximaler Diameter: $80 \mathrm{~mm}$ ). a In der MRT als hypervaskularisierte Läsion imponierend. b Korrespondierende fokale Region in der TTT-Auswertung, bei der $10 \%$ des Amplitudenmaximums schneller erreicht werden. 
The detection rates achieved by the two readers ranged from $50 \%$ to $90 \%$ ( Table 1, $\bullet$ Fig. 5, 6). The detection rate was highest $(90 \%, 80 \%)$ for the analysis of the PA of oxygenated hemoglobin and lowest for TTT analysis of both oxygenated $(60 \%, 50 \%)$ and deoxygenated hemoglobin $(60 \%, 60 \%)$.

False-positive classifications of predefined benign lesions were least common for the evaluation of FWHM (14.3\%, 14.3\%) but much higher for the other two parameters ( 0 Table 2). Additional lesions were most commonly identified when PA was used ( $80 \%$ and $90 \%$ of cases). The detection of additional lesions was lower for TTT and FWHM ( $60-65 \%$ and $55-70 \%$, respectively). If one interpreted the detection of additional lesions as the method's specificity, PA analysis by the second reader would yield a specificity of less than $10 \%$, for instance. Concordance between the two readers for the detection of the predefined lesion and for the detection of additional lesions was moderate to satisfactory (0.479 to 1$)$.

ROC analysis revealed AUC values ranging from $0.393-0.779$ (0 Table 3). None of the parameters analyzed differed significantly from random probability. The highest AUC value was identified for FWHM analysis of oxyhemoglobin concentrations, which

Table 3 AUC analysis in 17 lesions (10 malignant/7 benign lesions).

Tab. 3 AUC-Analyse von 17 Läsionen (10 maligne/7 benigne Läsionen).

\begin{tabular}{|c|c|c|c|c|}
\hline parameter & form of hemoglobin & reader & AUC & significance \\
\hline \multirow[t]{4}{*}{ TTT } & \multirow[t]{2}{*}{ oxyhemoglobin } & 1 & 0.514 & 0.922 \\
\hline & & 2 & 0.393 & 0.464 \\
\hline & \multirow[t]{2}{*}{ deoxyhemoglobin } & 1 & 0.729 & 0.118 \\
\hline & & 2 & 0.586 & 0.558 \\
\hline \multirow[t]{4}{*}{ FWHM } & \multirow[t]{2}{*}{ oxyhemoglobin } & 1 & 0.779 & 0.057 \\
\hline & & 2 & 0.779 & 0.057 \\
\hline & \multirow[t]{2}{*}{ deoxyhemoglobin } & 1 & 0.564 & 0.661 \\
\hline & & 2 & 0.421 & 0.591 \\
\hline \multirow[t]{4}{*}{ PA } & \multirow[t]{2}{*}{ oxyhemoglobin } & 1 & 0.593 & 0.526 \\
\hline & & 2 & 0.471 & 0.495 \\
\hline & \multirow[t]{2}{*}{ deoxyhemoglobin } & 1 & 0.400 & 0.845 \\
\hline & & 2 & 0.421 & 0.591 \\
\hline
\end{tabular}

tended to be above the $50 \%$ chance level and almost reached statistical significance $(\mathrm{p}<0.057)$.

Analysis of lesion visibility showed that the optimal situation of a clear-cut lesion, i.e., one that dominates other lesions in the breast parenchyma, is only present in $20-40 \%$ of patients with breast cancer ( $\odot$ Table 4$)$.

\section{Discussion \\ $\nabla$}

Over the last 20 to 30 years, many countries have introduced screening programs to reduce breast cancer mortality. In Germany, for example, breast cancer screening was introduced in 2006 [22-24]. The wider use of imaging modalities in the screening setting has also led to a greater awareness of the advantages and disadvantages of each imaging modality. Mammography is still the gold standard of breast imaging. However, it exposes women to ionizing radiation and can induce radiogenic DNA changes, which in turn may cause carcinogenic mutations [25]. MRI involves no radiation exposure and has the highest sensitivity of all imaging modalities used for breast cancer detection. However, its specificity is relatively poor [26]. MRI is still too expensive for use as a screening modality. Breast ultrasound is inexpensive but highly examiner-dependent [27], and it has very limited diagnostic accuracy in breast examinations [28].

Widely accepted advantages of optical imaging include the absence of radiation exposure and its relatively low cost [20] based on the relatively low investment cost of the components required to perform optical imaging.

Some studies use an extrinsic contrast agent such as ICG or Omocianine as a dye to enhance contrasts in optical imaging $[6,29]$. The possible advantages of using extrinsic contrast make optical imaging more complex and may represent a disadvantage for its use as a screening tool, which should be very easy to handle. Interestingly, the signal change measured after an adequately performed Valsalva maneuver is comparable to the change in absorption seen after bolus administration of $25 \mathrm{mg}$ of the extrinsic dye ICG [6]. For use in screening programs, it would be desirable to perform optical imaging without using an extrinsic dye. Breast screening requires not only high sensitivity but also high specificity to

Table 4 Visibility of predefined malignant lesions ( $=10$ ) based on visual scores (VS): I, predefined lesion not visible; II, predefined lesion visible but poorer color contrast compared with other lesions; III, predefined lesion visible with color contrast comparable to that of other lesions; IV, predefined lesion dominates the display.

Tab.4 Sichtbarkeit prädefinierter maligner Läsionen ( $n=10)$, basierend auf den Visual Scores (VS): I: prädefinierte Läsion nicht sichtbar; II, prädefinierte Läsionen sichtbar, aber schwächerer Farbkontrast verglichen mit anderen Läsionen; III, prädefinierte Läsionen sichtbar mit Farbkontrast, vergleichbar mit anderen Läsionen; IV, prädefinierte Läsionen dominieren die Aufnahme.

\begin{tabular}{|c|c|c|c|c|c|c|c|}
\hline parameter & form of hemoglobin & reader & VSI & VS II & VS III & VS IV & concordance \\
\hline \multirow[t]{4}{*}{ TTT } & \multirow[t]{2}{*}{ oxyhemoglobin } & 1 & $40 \%$ & $20 \%$ & $20 \%$ & $20 \%$ & \multirow[t]{2}{*}{0.571} \\
\hline & & 2 & $50 \%$ & $0 \%$ & $10 \%$ & $40 \%$ & \\
\hline & \multirow[t]{2}{*}{ deoxyhemoglobin } & 1 & $40 \%$ & $10 \%$ & $20 \%$ & $30 \%$ & \multirow[t]{2}{*}{0.565} \\
\hline & & 2 & $40 \%$ & $10 \%$ & $10 \%$ & $40 \%$ & \\
\hline \multirow[t]{4}{*}{ FWHM } & \multirow[t]{2}{*}{ oxyhemoglobin } & 1 & $30 \%$ & $30 \%$ & $20 \%$ & $20 \%$ & \multirow[t]{2}{*}{0.467} \\
\hline & & 2 & $30 \%$ & $20 \%$ & $0 \%$ & $50 \%$ & \\
\hline & \multirow[t]{2}{*}{ deoxyhemoglobin } & 1 & $30 \%$ & $20 \%$ & $20 \%$ & $30 \%$ & \multirow[t]{2}{*}{0.444} \\
\hline & & 2 & $30 \%$ & $0 \%$ & $20 \%$ & $50 \%$ & \\
\hline \multirow[t]{4}{*}{ PA } & \multirow[t]{2}{*}{ oxyhemoglobin } & 1 & $10 \%$ & $50 \%$ & $20 \%$ & $20 \%$ & \multirow[t]{2}{*}{0.146} \\
\hline & & 2 & $20 \%$ & $0 \%$ & $60 \%$ & $20 \%$ & \\
\hline & \multirow[t]{2}{*}{ deoxyhemoglobin } & 1 & $20 \%$ & $20 \%$ & $40 \%$ & $20 \%$ & \multirow[t]{2}{*}{0.737} \\
\hline & & 2 & $30 \%$ & $20 \%$ & $20 \%$ & $30 \%$ & \\
\hline
\end{tabular}


avoid too many false-positive results, which could lead to invasive interventions [30]. Summarizing prior studies according to Grosenick et al. it seems unlikely that this goal will be reached by optical mammography based on intrinsic contrast alone in a conceivable time [30]. In an attempt to overcome the previous limitations, we tried a new approach amplifying the intrinsic contrast with a Valsalva maneuver in our study.

Near-infrared imaging using intrinsic contrasts can exploit differences in hemoglobin concentrations resulting from the abnormal vascular architecture of neoangiogenic vessels to identify malignant tumors [20]. Tumor vessels are disorganized, functionally abnormal, and hyperpermeable [31]. How this affects hemodynamics is still largely unknown and may be expected to differ among tumor types. Some authors assume that resistance to blood flow is increased in a malignant tumor resulting in sluggish changes in blood flow [20,32, 33]. Following a Valsalva maneuver it is expected that the increase in hemoglobin concentration lasts longer in the tumorous area compared to benign tissue.

Other investigators attach more importance to an increased vascular density in tumors, which may underlie the high perfusion of some tumor entities [34, 35]. As a result, malignant lesions show a faster amplitude increase following administration of an extrinsic contrast agent, while benign lesions such as fibroadenomas will show delayed enhancement [36].

A delayed response to changes in blood flow in malignant tumors is expected to result in a greater full width at half maximum. Among the parameters analyzed in our study, FWHM had the highest AUC value, and the p-value almost reached statistical significance.

The assumption of higher vascular density and short circuits in malignant tumors, leading to higher perfusion of the tumor might correspond with changes in the magnitude of the peak amplitude and its slope. However, in our study, neither analysis using PA or TTT resulted in a lesion detection rate that was significantly different from random probability.

Overall, the detection rates we achieved using the DYNOT 232 system are comparable to the detection rates reported for optical imaging in other studies, which are on the order of $85 \%$ [37]. In a study investigating optical imaging of the breast with the contrast agent ICG, Schneider et al. reached a sensitivity of $85.7 \%$ and a specificity of $87.5 \%$ for malignant lesions with a time-topeak-based analysis of the amplitude of the increasing signal after ICG injection [6]. Using Omocianine-enhanced optical mammography in the fluorescence mode, Poellinger et al. reached a detection rate of $55.6 \%$ for all dose groups, with detection rates of up to $100 \%$ for special dose groups [19]. The rate of false-positive lesions was $17.6 \%$. In the absorption mode the detection rate for malignant target lesions was $44.4 \%$. The false-positive rate for benign lesions was $11.8 \%$. In another study using ICG, Poellinger et al. analyzed optical mammography in the fluorescence mode and achieved a mean sensitivity of $92 \%$ and a mean specificity of $75 \%$ [29].

A considerable drawback of using the Valsalva maneuver is that there is very wide interindividual variation in how it is performed. In our study, each patient was instructed carefully and practiced the maneuver repeatedly before being examined. Nevertheless, one-third of the examinations were not analyzable due to signal artifacts and inadequate Valsalva maneuvers. In some patients, inspiratory motion might have resulted in detachment of the optodes from the skin. In other patients, we did not observe the expected increase in oxyhemoglobin and deoxyhemoglobin but instead saw a signal drop, suggesting that Valsalva maneuvers induced a decrease rather than increase in intrathoracic pressure. It appears very difficult to standardize Valsalva maneuvers. A standardized analysis of all patients including patients with inadequately performed Valsalva maneuver would lead to a significant decrease in sensitivity, since tumors in these patients could not be visualized correctly. Also, the overall specificity could become worse.

If we only look at the patients with analyzable examinations, the sensitivity appears to be acceptable. However, the rate of falsepositive additional lesions is unacceptably high. These false-positive lesions result in extremely low specificities (roughly estimated $<10 \%$ ). The appearance of many circumscribed regions with larger FWHM and increased peak amplitude or short TTT within the breast suggests that the delayed hemodynamic response and increase in amplitude assumed to suggest malignant breast lesions does not appear to be confined to malignant breast tissue. The two studies suggesting that the hemodynamic changes induced by Valsalva maneuver have potential for contributing to the detection of malignant breast lesions also used the NIRx tomography system. Different from our study, however, both of these studies imaged both breasts simultaneously. In their feasibility study, Schmitz et al. used 32 emission and detection optodes and two wavelengths ( $760 \mathrm{~nm}$ and $830 \mathrm{~nm}$ ). Flexman et al. used 32 emission and 64 detector optodes and also two wavelengths ( $765 \mathrm{~nm}$ and $835 \mathrm{~nm}$ ), investigating two patients with breast cancer and one healthy woman. The imaging data were processed using a threshold for changes in hemoglobin as a basis for three-dimensional visualization. Using individual thresholds - $4 \%$ hemoglobin change in one woman and $18 \%$ change in the other woman - the authors identified breast cancer and showed that no increase in hemoglobin occurred during the maneuver in the healthy control subject. Schmitz et al. found a higher hemoglobin concentration in malignant areas compared to the contralateral healthy breast and non-diseased tissue in the tumor-bearing breast. The increase persisted for some time after the Valsalva maneuver. As a result, the return to the baseline hemoglobin concentration was markedly delayed in areas of breast cancer compared with the healthy breast.

Our study investigated changes in hemodynamics in a larger group of patients for the first time. The images generated by optical tomography were analyzed by two blinded readers. We used a standardized approach for analysis, while Flexman et al. used individual thresholds in their two patients and the healthy subject.

Schmitz et al. and Flexman et al. evaluated delayed return to baseline following Valsalva maneuver for identifying breast lesions. Such a delay is also reflected in the parameters we analyzed. FWHM is a measure of amplitude width, which means that higher values correspond with delayed return to baseline. Nevertheless, there appear to be too many other factors that affect hemodynamics after a Valsalva maneuver, precluding its use for specific detection of malignant breast lesions. Moreover, the Valsalva maneuver is subject to great interindividual variation. Schmitz et al. also mentioned that the reliability of this parameter crucially relies on how accurately the patient can perform the Valsalva maneuver.

Our study is limited by the fact that we performed optical imaging of only one breast. Abnormalities in vascular architecture and hemodynamics, however, may extend far beyond the actual lesion, also affecting adjacent healthy breast parenchyma. Our observation that the readers in our study identified numerous additional breast lesions suggests that even optical imaging of both breasts would not have helped in accurately locating a lesion within the 
breast. A further study might investigate whether evaluation of hemodynamics by optical imaging can differentiate the whole breasts with malignant lesions (instead of differentiating the lesion only) from normal breasts or breasts with benign lesions. This question cannot be answered by our study. However, in patients with bilateral cancer, imaging of both breasts would not contribute to better detection as no differences would be apparent.

A general limitation of the approach under investigation is that changes in vascular function and hemodynamics in malignant breast lesions are not yet fully understood. All we have at present are hypotheses, making it very difficult to establish valid models for interpreting the results of optical imaging.

\section{Conclusion}

\section{$\nabla$}

Dynamic optical NIR imaging using the Valsalva maneuver to enhance intrinsic contrast shows acceptable sensitivity. However, due to its very low specificity, this method does not appear to be a suitable candidate for breast imaging. A major drawback of the method is the difficulty to standardize the Valsalva maneuver resulting in a high number of artifacts. In a clinical setting inadequately performed Valsalva maneuvers can lead to a decrease in sensitivity, since one-third of the performed examinations could not be further analyzed.

\section{Acknowledgements}

This research was supported by the National Institutes of Health (NIH) under grants R41CA096102 and R01CA066184, by the U.S. Army under grant DAMD017-03-C-0018, and by the New York State Department of Health. Some of the devices used in this research are a product of NIRx Medical Technologies, LLC.

\section{References}

1 Jemal A, Siegel R, Ward E et al. Cancer statistics, 2008. CA: a cancer journal for clinicians 2008; 58: 71-96

2 Carter CL, Allen C, Henson DE. Relation of tumor size, lymph node status, and survival in 24,740 breast cancer cases. Cancer 1989; 63: 181 187

3 Clark GM, Sledge GWJr, Osborne CK et al. Survival from first recurrence: relative importance of prognostic factors in 1,015 breast cancer patients. Journal of clinical oncology: official journal of the American Society of Clinical Oncology 1987; 5: 55-61

4 Hayes DF. Tumor markers for breast cancer. Annals of oncology: official journal of the European Society for Medical Oncology/ESMO 1993; 4: $807-819$

5 Van Lancker M, Goor C, Sacre R et al. Patterns of axillary lymph node metastasis in breast cancer. American journal of clinical oncology 1995; 18: 267-272

6 Schneider P, Piper S, Schmitz CH et al. Fast 3D Near-infrared breast imaging using indocyanine green for detection and characterization of breast lesions. Fortschr Röntgenstr 2011; 183: 956 -963

7 Fischer U, Schwethelm L, Baum FT et al. Effort, accuracy and histology of MR-guided vacuum biopsy of suspicious breast lesions - retrospective evaluation after 389 interventions. Fortschr Röntgenstr 2009; 181: $774-781$

8 Baltzer PA, Dietzel M, Vag T et al. Can color-coded parametric maps improve dynamic enhancement pattern analysis in MR mammography? Fortschr Röntgenstr 2010; 182: 254-260

9 Muller-Schimpfle MP, Heindel W, Kettritz U et al. Consensus Meeting of Course Directors in Breast Imaging, 9 May 2009, in Frankfurt am Main - Topic: Masses. Fortschr Röntgenstr 2010; 182: 671-675
10 Adamietz B, Schulz-Wendtland R, Meier-Meitinger M. Asymptomatic siliconoma after prosthesis rupture: portrayal using elastography. Fortschr Röntgenstr 2009; 181: 385-386

11 Siegmann KC, Moron HU, Baur A et al. Diagnostic value of a breast MRI score for the prediction of malignancy of breast lesions detected solely with MRI. Fortschr Röntgenstr 2009; 181: 556-563

12 Siegmann KC, Muller KT, Vogel $U$ et al. MR imaging of the breast before and after neoadjuvant treatment - enhancement characteristics and T 2 signal intensity of breast cancers and breast parenchyma. Fortschr Röntgenstr 2010; 182: $493-500$

13 Siegmann KC, Speck S, Baur A et al. Performance of a newly developed clip (Tumark Professional) for MRI-guided lesion localization after MRI-guided vacuum-assisted biopsy - first results. Fortschr Röntgenstr 2009; 181: 147-154

14 Schmitt B, Zamecnik P, Zaiss $M$ et al. A new contrast in MR mammography by means of chemical exchange saturation transfer (CEST) imaging at 3 Tesla: preliminary results. Fortschr Röntgenstr 2011; 183: 1030 1036

15 Weissleder R, Pittet MJ. Imaging in the era of molecular oncology. Nature 2008; 452: 580-589

16 Tromberg BJ, Shah $N$, Lanning $R$ et al. Non-invasive in vivo characterization of breast tumors using photon migration spectroscopy. Neoplasia 2000; $2: 26-40$

17 Gibson AP, Hebden JC, Arridge SR. Recent advances in diffuse optical imaging. Physics in medicine and biology 2005; 50: R1 - 43

18 Hielscher $A H$. Optical tomographic imaging of small animals. Current opinion in biotechnology 2005; 16: 79-88

19 Poellinger A, Persigehl T, Mahler $M$ et al. Near-infrared imaging of the breast using omocianine as a fluorescent dye: results of a placebo-controlled, clinical, multicenter trial. Investigative radiology 2011; 46: 697-704

20 Flexman ML, Khalil MA, Al Abdi R et al. Digital optical tomography system for dynamic breast imaging. Journal of biomedical optics 2011, 16

21 Schmitz CH, Klemer DP, Hardin R et al. Design and implementation of dynamic near-infrared optical tomographic imaging instrumentation for simultaneous dual-breast measurements. Appl Opt 2005; 44: $2140-2153$

22 Hofvind S, Skaane P. Stage Distribution of Breast Cancer Diagnosed Before and After Implementation of Population-Based Mammographic Screening. Fortschr Röntgenstr 2012; 184: 437-442

23 Czwoydzinski J, Girnus R, Sommer A et al. Central online quality assurance in radiology: an IT solution exemplified by the German Breast Cancer Screening Program. Fortschr Röntgenstr 2011; 183: 849-854

24 Weigel S, Batzler WU, Decker T et al. First epidemiological analysis of breast cancer incidence and tumor characteristics after implementation of population-based digital mammography screening. Fortschr Röntgenstr 2009; 181: $1144-1150$

25 Jackman RJ, Marzoni FA Jr. Stereotactic histologic biopsy with patients prone: technical feasibility in $98 \%$ of mammographically detected lesions. American journal of roentgenology 2003; 180: 785-794

26 Warner E, Messersmith H, Causer P et al. Systematic review: using magnetic resonance imaging to screen women at high risk for breast cancer. Annals of internal medicine 2008; 148: 671 - 679

27 Elmore JG, Armstrong $K$, Lehman CD et al. Screening for breast cancer. JAMA: the journal of the American Medical Association 2005; 293: $1245-1256$

28 Kuhl CK, Schrading S, Leutner CC et al. Mammography, breast ultrasound, and magnetic resonance imaging for surveillance of women at high familial risk for breast cancer. Journal of clinical oncology: official journal of the American Society of Clinical Oncology 2005; 23: 84698476

29 Poellinger A, Burock S, Grosenick D et al. Breast cancer: early- and latefluorescence near-infrared imaging with indocyanine green - a preliminary study. Radiology 2011; 258: 409-416

30 Grosenick D, Moesta KT, Moller M et al. Time-domain scanning optical mammography: I. Recording and assessment of mammograms of 154 patients. Physics in medicine and biology 2005; 50: 2429-2450

31 Jain RK. Normalizing tumor vasculature with anti-angiogenic therapy: a new paradigm for combination therapy. Nature medicine 2001; 7: 987-989

32 Suzuki M, Hori K, Abe I et al. Functional characterization of the microcirculation in tumors. Cancer metastasis reviews 1984; 3: 115-126

33 Fukumura D, Duda DG, Munn LL et al. Tumor microvasculature and microenvironment: novel insights through intravital imaging in pre-clinical models. Microcirculation 2010; 17: 206-225 
34 Tsutsui S, Kume M, Era S. Prognostic value of microvessel density in invasive ductal carcinoma of the breast. Breast Cancer 2003; 10: 312 319

35 Weidner N, Semple JP, Welch WR et al. Tumor angiogenesis and metastasis - correlation in invasive breast carcinoma. The New England journal of medicine $1991 ; 324: 1-8$
36 Alacam B, Yazici B, Intes X et al. Pharmacokinetic-rate images of indocyanine green for breast tumors using near-infrared optical methods. Physics in medicine and biology 2008; 53: 837-859

37 Leff DR, Warren OJ, Enfield LC et al. Diffuse optical imaging of the healthy and diseased breast: a systematic review. Breast Cancer Res Treat 2008; 108: 9-22

Buchbesprechung

Computed Tomography: From Photon Statistics to Modern Cone-Beam CT

Buzug TM

1. Aufl. (2008 - als Taschenbuch 2010), Springer Verlag: Berlin, 522 S., 475 Abb., 74,85 € (68,99 € als Taschenbuch),

ISBN: 978-3-540-39407-5

Die Computertomografie (CT) ist heutzutage ein in der klinischen Routine bestens etabliertes Verfahren für die Diagnose und ein notwendiges Hilfsmittel für eine große Palette von verschiedensten Therapieformen im Gesundheitswesen.

Die bemerkenswerte Symbiose aus Physik, Mathematik und Ingenieurswesen macht die rasante Entwicklung in der CTBildgebung zu einem wertvollen Bestandteil der Diagnostik. Dieses Buch, nun auch als Taschenbuch erschienen, erreicht zum einen ein intuitives Verstehen der CT und zum anderen eine stringente und konsistente Beschreibung der zugrunde liegenden Prinzipien der CT. Diese beiden beabsichtigten und in bemerkenswerter Weise umgesetzten Zielvorgaben machen das Buch zu einem wertvollen CT-Nachschlagewerk und zu einem Lehrbuch für alle Lernenden, die eine umfassende Darstellung der CT suchen.

Das Werk beschreibt die Grundlagen der Strahlenphysik inklusive der Erzeugung von Röntgenstrahlen und der Wechselwirkung von Strahlung und Materie. Darauf aufbauend eine detailreiche Einführung in die röntgenbasierte Bildgebung. Eine besondere Berücksichtigung findet die Darstellung der Prinzipien in der Signalverarbeitung, welche nahezu in allen anschließenden Kapiteln zum Verständnis benötigt werden. Das Herzstück des Buches bildet die Besprechung der Bildrekonstruktion, die sich über mehrere Kapitel erstreckt und trotz der übersichtlichen und klar gegliederten mathematischen Grundlagen unabdingbar manchmal etwas schwer verdaulich wirkt.

Das Buch beginnt mit einer Interesse weckenden und lesenswerten, historischen Einführung über die CT mit vielen Bildern der Zeitgeschichte. Nach Klärung der fundamentalen Grundbegriffe der röntgenbasierten Bildgebung und einer Einführung in das für das Verständnis des Buches notwendige Basiswissen der Strahlenphysik zeigt das dritte Kapitel die Meilensteine zur CT mit einer kurzen Beschreibung einiger assoziierten Technologien wie Micro-CT und PET-CT-Scanner.

Es folgen nun in einer beachtlichen Anzahl Kapitel über SignalVerarbeitung, 2-D-Fourier-Transformation und algebraische und statistische Rekonstruktionsverfahren. Diese Kapitel bleiben angesichts des zu erwartenden komplexen mathematischen Formalismus auch für Nicht-Spezialisten nachvollziehbar.
Allerdings werden an einigen Stellen mehr als fortgeschrittene mathematische Kenntnisse vorausgesetzt, um die bemüht einfach gehaltenen Formalismen zu verstehen, denn es gelingt dem Autor nicht immer eine stringente mathematische Ableitung und simplifizierte Verständlichkeit zu kombinieren. Man kann diese Vorgehensweise auch positivieren, indem man dem Autor zugute hält, dass er ein breites Spektrum von Lesern mit unterschiedlichen mathematischen Vorkenntnissen ansprechen möchte.

Die Bilder und Diagramme sind von hoher Qualität und ergänzen den Text vorbildlich. Als nachteilig wird die Qualität der 3-D-Bilder in den Abbildungen 1.8, 9.26, und 9.28 empfunden. Diese Abbildungen entsprechen leider nicht der Leistungsfähigkeit moderner CT-Scanner und fallen gegenüber den übrigen Abbildungen deutlich ab.

Die folgenden Kapitel über die Rekonstruktionsverfahren beschäftigen sich mit der Problematik wie Algorithmen eine von kontinuierlichen Daten ausgehende Theorie auf diskrete Daten adaptieren und die sich daraus ergebenden Konsequenzen. Darauf folgt in einem Kapitel wie diese Konsequenzen sich technisch in der Praxis abbilden lassen und technologisch umgesetzt werden.

Der Höhepunkt des Buches ist das längliche Kapitel über 3-DRekonstruktionen. Das detailreiche Kapitel präsentiert sich als äußerst komplex, was der Thematik geschuldet und teilweise zu erwarten ist. Der rote Faden in diesem Kapitel wird strikt verfolgt, nur erscheint die sprachliche Linie für einen NichtMuttersprachler nur mit erheblichem Aufwand verfolgbar. Das Buch schließt mit einem Kapitel über Bildqualität, Artefakte, praxisorientierte Aspekte und Dosis.

Fazit:

Das Buch ist verständlich geschrieben und kann sowohl als umfassendes Nachschlagewerk und als auch Lehrbuch genutzt werden. Dem Autor gelingt es, die Physik und die Mathematik hinter der CT in einer verständlichen Art darzustellen.

Es stellt sich allerdings die Frage: Brauchen wir noch ein weiteres englischsprachiges Buch über die Grundlagen der Computertomografie mit Adaption auf moderne Entwicklungen?

Dr. Stephan Garbe, Bonn 